\title{
First detection of the cosmopolitan invader Leptoglossus occidentalis Heidemann (Heteroptera: Coreidae) in Argentina
}

\author{
MARCELO E. KUN ${ }^{1}$ and MAITÉ MASCIOCCHI ${ }^{2}$ \\ ${ }^{1}$ Laboratorio de Zoología, Centro Regional Universitario Bariloche, Universidad \\ Nacional del Comahue, Quintral 1250, Bariloche (8400), Argentina \\ ${ }^{2}$ Grupo de Ecología de Poblaciones de Insectos, IFAB-CONICET-INTA EEA \\ Bariloche, Av. Modesta Victoria 4450, Bariloche (8400), Argentina \\ Manuscript received on May 21, 2018; accepted for publication on March 29, 2019
}

\begin{abstract}
How to cite: KUN ME AND MASCIOCCHI M. 2019. First detection of the cosmopolitan invader Leptoglossus occidentalis Heidemann (Heteroptera: Coreidae) in Argentina. An Acad Bras Cienc 91: e20180493. DOI. 10.1590/0001-3765201920180493.

Abstract: Leptoglossus occidentalis Heidemann is a conifer seed bug, native to North America. This species is considered invasive and has reached several countries in the Northern Hemisphere and most recently Chile in South America. This work reports the first detection of this species in Argentina, with specimens from the Rio Negro province, in 2017. Ecological traits and its potential rapid spread were also discussed.
\end{abstract}

Key words: Exotic species, Foliated chinch bug, Invader, Pine plantation, Pinus spp.

\section{INTRODUCTION}

Leptoglossus occidentalis, frequently known as Western conifer seed bug, is an hemipteran belonging in the family Coreidae (Fig. 1). The first description of this species was carried out from specimens found in California, Colorado and Vancouver (Heidemann 1910). It is native to North America and its distribution ranges from Southern Canada to the North of Mexico, being frequently found in the United States (Allen 1969). In the last years, L. occidentalis rapidly spread to Japan (Ishikawa and Kikuhara 2009), China (Zhu 2010), Europe (Fent and Kment 2011, Brailovsky 2014, Nemer 2015, Van der Heyden 2018a, b), Russia (Gapon 2013), North of Africa (Jamâa et al. 2013,

Correspondence to: Maité Masciocchi

E-mail: maimasciocchi@gmail.com

ORCid: https://orcid.org/0000-0002-0095-2170
Gapon 2015) and Chile (Faúndez and Rocca 2017, Faúndez et al. 2017, 2018a, b).

Leptoglossus occidentalis is known as an important pest of conifer seeds of Pinus spp. (Fent and Kment 2011, Gapon 2013, 2015, Faúndez et al. 2017); however, other genera as Pseudotsuga (Fent and Kment 2011), Juniperus, Tsuga, Picea, Cedrus, Calocedrus (Petrakis 2011) and exceptionally Pistacia (Uyemoto et al. 1986), can be attacked. Key visual expedite diagnostic features that must be concurrently present of an adult of Leptoglossus occidentalis are: the ivory or pale yellow hemelytral venation, the overall body colour dark reddish brown with pronotum and venter mottled with numerous piceous spots with their humeral angle broadly rounded, and their outer tibial dilations entire not dentate, weakly wider than the inner ones but of equal length occupying less than $70 \%$ of 


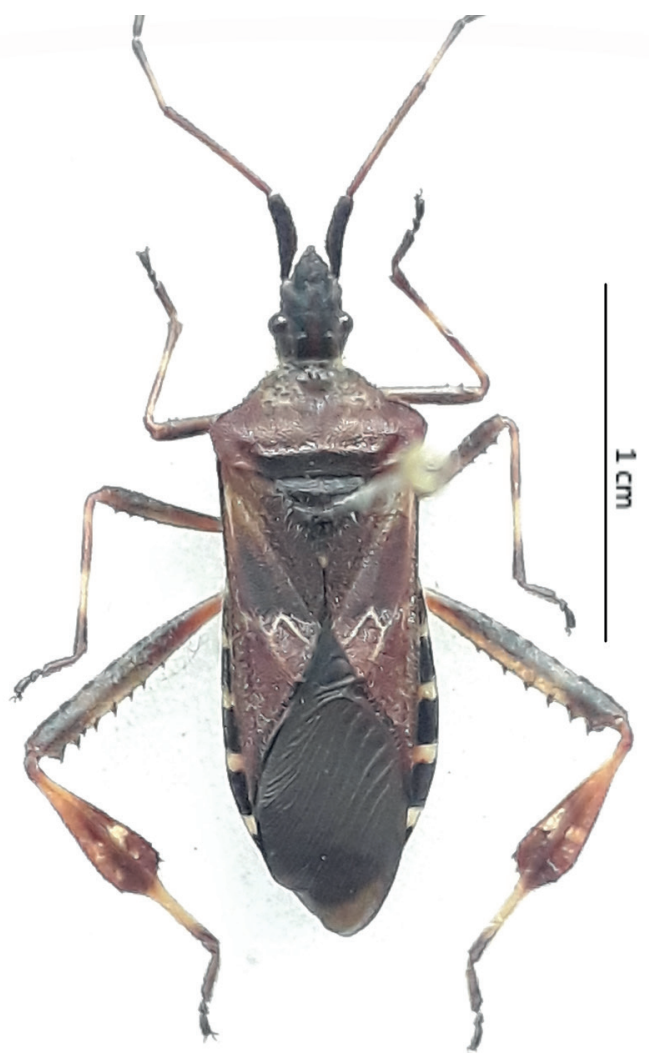

Figure 1 - Dorsal view of an adult of Leptoglossus occidentalis.

hind tibia (Allen 1969, Brailovsky 2014) (Fig. 2). The outer dilation of $L$. occidentalis may also be confused with these of Leptoglossus crassicornis, also present in Argentina; these can be differentiated because in $L$. crassicornis these are more slender and elongate, whereas in L. occidentalis these are widened in the apical section, and less elongated (Faúndez et al. 2018b).

This leaf-footed bug exhibits enough plasticity to complete one or several generations per year depending on environmental conditions where it thrives. In the United States it shows univoltinism, while in Mexico it can develop three generations per year (Mitchell 2000). The adults emerge from hibernating sites and oviposit on pine needles of the host plant. Nymphs and adults hurt the seed by inserting their proboscis into the cones of conifers and feed on seed content and succulent tissues of the cones; nevertheless, subsequent instars and

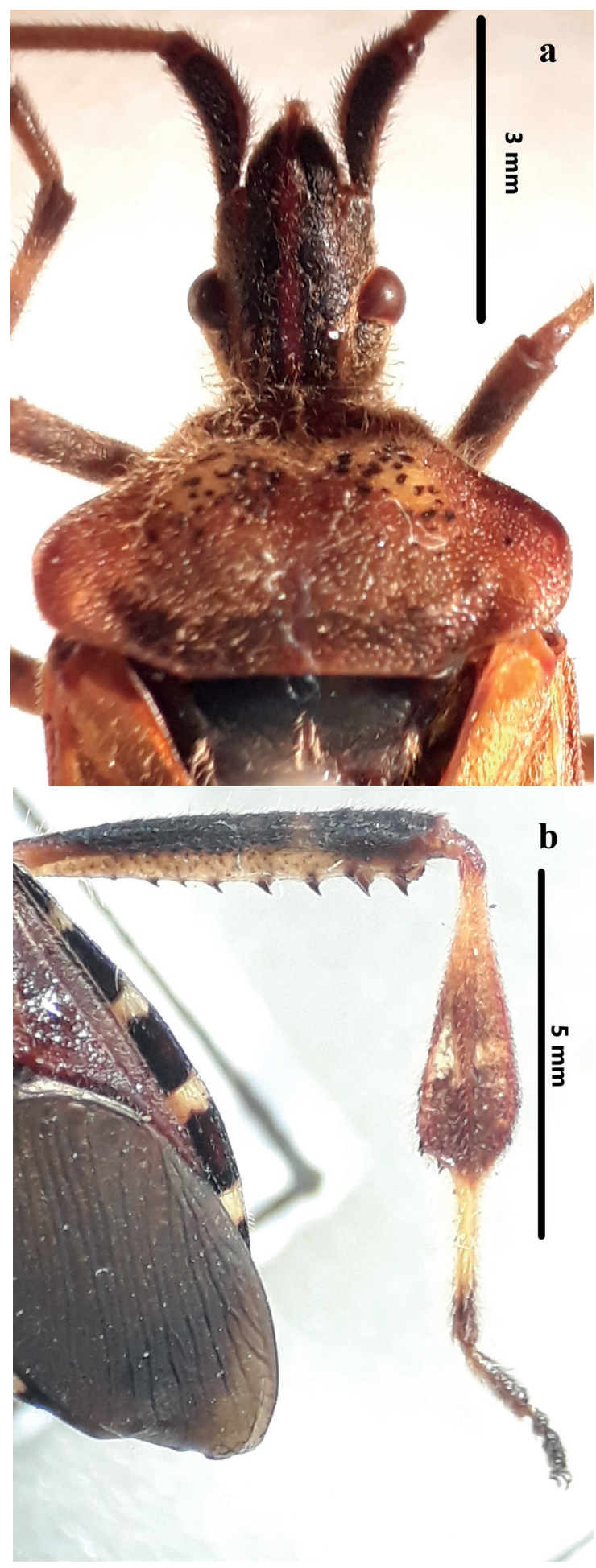

Figure 2 - Key visual expedite diagnostic features of an adult of Leptoglossus occidentalis. a) Overall body colour dark reddish brown with pronotum and venter mottled with numerous piceous spots with their humeral angle broadly rounded; b) the outer tibial dilations entire not dentate, weakly wider than the inner one. 
adults only feed on cones' tissues. A single cone can host many specimens as nymph instars and adults. In the winter, adults aggregate and enter the hibernating status. This frequently take place under the bark of the trees, in the soil, rodent nests and in human buildings (Dennys 1927, Hussey 1953).

First detection of L. occidentalis in Argentina was in December 2017, in El Bolson (Río Negro

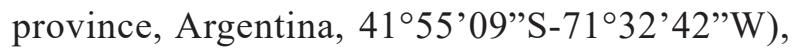
on conifer trees. Thereafter other detections were registered on the same tree species, at the localities of Bariloche and Dina Huapi $\left(41^{\circ}\right.$

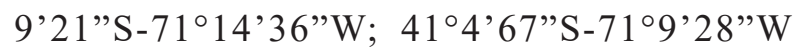
respectively). The specimens were sent to the Zoology Laboratory in the Bariloche Regional University Center depending of the Comahue National University, where the taxonomic identification was carried out. The species was determined by using keys for the genus Leptoglossus and for the tribe Anisoscelini (Brailovsky 2014, Coscaron and Pall 2015). The specimens could not be clearly keyed out with any Leptoglossus species already registered for Argentina included in Coscaron and Pall's taxonomic work (2015); although these fully agree with Leptoglossus occidentalis Heidemann in Brailovsky's taxonomic work (2014), with the original description (Heidemann 1910) and the old revision of the genus Leptoglossus (Allen 1969). Therefore, this becomes the first detection of Leptoglossus occidentalis Heidemann in Argentina. The recent detection of this species in Chile (Faúndez et al. 2017) suggests that the arrival in Argentina could have just been realized through the Northern Patagonian Chile-Argentina border (Faúndez and Rocca 2017, Faúndez et al. 2018a). It is to be expected that the geographical extension of $L$. occidentalis had been related with the distribution of their coniferous host plants, suggesting that climate is the main limiting factor of the distribution of the bug (Zhu et al. 2014).
Biological invasions have attracted the attention of the ecologists for many decades (Richardson and Pyšek 2007, Liebhold and Tobin 2008, Valéry et al. 2008). In the last times, the increase of commerce, and transfer of goods and people from one site to another has favoured the movement, intentional or accidental, of species to regions where they were not found previously. However, only a small proportion of those species, which arrive to a new area, successfully establish reaching populations sustained over time. These exotic species can become a threat for the host plants, the native biota and the invaded habitat. It is not clear the real environmental impact or the economic damage that Leptoglossus occidentalis could cause given their recent expansion across the world. In Argentina, up to this point, there are no studies advising the impact that this species could have on local congeneric (i.e., L. impictus, L. chilensis and L. concaviusculus), pine plantations, native conifer species and human populations (Faúndez and Carvajal 2011, Hornok and Kontschán 2017). Zhu et al. (2014) suggested that an eventual introduction of $L$. occidentalis in the Southern Hemisphere is therefore not likely to result in establishment. However, the dispersion capability demonstrated by this bug, the ability to develop in different species of conifers and their plasticity related to the hibernation sites, added to the 5 million hectares of pine planted in South America (Corley et al. 2019), seem to be factors that would favour the successful spread and high rate of survival of these species in this new environments.

The few records reported in Argentina indicate that at this time L. occidentalis is recently arriving; however, the high spreading rate, reported in other invaded areas, suggests a quick establishment added to a serious threats to north Patagonian conifer species, if policy survey and control measures are not undertaken. Careful studies on ecology and behaviour for this bug in an invaded area must be carried out. 


\section{ACKNOWLEDGMENTS}

This study was financed by grants to Marcelo Kun, CRUB, Universidad Nacional del Comahue project B215 (ORD N915 29/10/2017) provided by the Universidad Nacional del Comahue and to Masciocchi Maité (PICT 2015-1150) provided by the Argentinean Agencia de Promoción Científica y Técnica.

\section{AUTHOR CONTRIBUTIONS}

MK provided the specimens and data.

MK and MM participated in the writing of the manuscript and have approved the submitted version.

\section{REFERENCES}

ALLEN RC. 1969. A revision of the genus Leptoglossus Guérin (Hemiptera: Coreidae). Entomol Am 45: 35-140.

BRAILOVSKY H. 2014. Illustrated key for identification of the species included in the genus Leptoglossus (Hemiptera: Heteroptera: Coreidae: Coreinae: Anisoscelini), and descriptions of five new species and new synonyms. Zootaxa 3794: 143-178.

CORLEY JC, LANTSCHNER MV, MARTÍNEZ AS, FISCHBEIN D AND VILLACIDE JM. 2019. Management of Sirex noctilio populations in exotic pine plantations: critical issues explaining invasion success and damage levels in South America. J Pest Sci 92: 131-142.

COSCARON MC AND PALL J. 2015. The Tribe Anisoscelini (Hemiptera: Heteroptera, Coreidae) in Argentina. Zootaxa 4033: 411-426.

DENNYS AA. 1927. Some notes on the hibernating habits of insects in dry trees in the interior of B. C. J Ent Soc Br Columb 24: 19-25.

FAÚNDEZ E, ROCCA J AND VILLABLANCA J. 2017. Detection of the invasive western conifer seed bug Leptoglossus occidentalis Heidemann, 1910 (Heteroptera: Coreidae: Coreinae) in Chile. Arq Entomol 17: 317-320.

FAÚNDEZ EI AND CARVAJAL MA. 2011. Primer registro de una picadura de Leptoglossus chilensis (Spinola, 1852) (Hemiptera: Heteroptera: Coreidae) en un ser humano. Boletín de Biodiversidad de Chile 6: 22-25.

FAÚNDEZ EI, LÓPEZ-ALISTE M AND CARVAJAL MA. 2018b. First ocurrence of Leptoglossus crassicornis (Dallas) (Heteroptera: Coreidae) in Chile, with a key to the species of Leptoglossus Guerin-Meneville recorded in the country. Rev Chil Entomol 44: 410-415.

FAÚNDEZ EI AND ROCCA JR. 2017. La chinche de las coníferas occidental, Leptoglossus occidentalis Heidemann
(Heteroptera: Coreidae) en Chile; rápida expansión, posibles impactos y desafíos. Rev Chil Entomol 42: 25-27.

FAÚNDEZ EI, ROCCA JR AND VILLABLANCA J. 2018a. On the establishment of the Western Conifer Seed Bug Leptoglossus occidentalis Heidemann (Heteroptera: Coreidae) in Chile. Rev Chil Entomol 44: 207-210.

FENT M AND KMENT P. 2011. First record of the invasive western conifer seed bug Leptoglossus occidentalis (Heteroptera: Coreidae) in Turkey. North-West J Zool 7: $72-80$

GAPON AD. 2013. First Records of the western confier seed bug Leptoglossus occidentalis Heid. (Heteroptera, Coreidae) from Russia and Ukraine, Regularities in its distribution and possibilities of its range expansion in the Palaearctic Region. Entomol Rev 93: 174-181.

GAPON AD. 2015. First record of Leptoglossus occidentalis (Heteroptera: Coreidae) in Morocco. Heteropterus Rev Entomol 15: 161-163.

HEIDEMANN O. 1910. New species of Leptoglossus from North America. [Hemiptera; Coreidae]. Proc Entomol Soc Wash 12: 191-197.

HORNOK S AND KONTSCHÁN J. 2017. The western conifer seed bug (Hemiptera: Coreidae) has the potential to bite humans. J Med Entomol 54: 1073-1075.

HUSSEY RF. 1953. Concerning some North American Coreidae (Hemiptera). Bull Brook EntomoI Soc 48: 29-34.

ISHIKAWA T AND KIKUHARA Y. 2009. Leptoglossus occidentalis Heidemann (Hemiptera: Coreidae), a presumable recent invader to Japan. Jpn J Entomol 12: 115-116.

JAMÂA MB, MEJRI M, NAVES P AND SOUSA E. 2013. Detection of Leptoglossus occidentalis Heidemann, 1910 (Heteroptera: Coreidae) in Tunisia. Afr Entomol 21: 165-167.

LIEBHOLD AM AND TOBIN PC. 2008. Population ecology of insect invasions and their management. Annu Rev Entomol 53: 387-408.

MITCHELL PL. 2000. Leaf-footed bugs (Coreidae). In: Schaefer CW and Panizzi AR (Eds), Heteroptera of economic importance, CRC press, p. 337-403.

NEMER N. 2015. Report on insect pests associated with conelet losses and their management in Pinus pinea forests in Lebanon. FAO, Rome, 45 p.

PETRAKIS PV. 2011. First record of Leptoglossus occidentalis (heteroptera: Coreidae) in greece. Entomol Hell 20: 83-93.

RICHARDSON DM AND PYŠEK P. 2007. Elton, CS 1958 : The ecology of invasions by animals and plants. London: Methuen. Prog Phys Geogr 31: 659-666.

UYEMOTO JK, OGAWA JM, RICE RE, TERANISHI HR, BOSTOCK RM AND PEMBERTON WM. 1986. Role of several true bugs (Hemiptera) on incidence and seasonal development of pistachio fruit epicarp lesion disorder. J Econo Entomol 79: 395-399.

VALÉRY L, FRITZ H, LEFEUVRE JC AND SIMBERLOFF D. 2008. In search of a real definition of the biological invasion phenomenon itself. Biol Inv 10: 1345-1351. 
VAN DER HEYDEN T. 2018a. Primera cita de Leptoglossus occidentalis Heidemann, 1910 (Hemiptera: Heteroptera: Coreidae: Coreinae: Anisoscelini) en los Altos del Golán. Rev Gad Entomol 7: 1-3.

VAN DER HEYDEN T. 2018b. First record of Leptoglossus occidentalis Heidemann (Heteroptera: Coreidae: Coreinae: Anisoscelini) in Albania. Rev Chil Entomol 44: 355-356.
ZHU GP, RÉDEI D, KMENT P AND BU WJ. 2014. Effect of geographic background and equilibrium state on niche model transferability: predicting areas of invasion of Leptoglossus occidentalis. Biol Inv 16: 1069-1081.

ZHU WB. 2010. Exotic coreid bugs introduced into China. In: Proceedings of the 4th meeting of the International Heteropterist's Society. Nankai University, Tianjin, China, July 12-17, 2010. Nankai University, Tianjin, 73 p. 